\title{
Technical Efficiency of Farms, and Fight Against Poverty: Case of the Cashew Sector in Côte d'Ivoire
}

\author{
Noufou Coulibaly ${ }^{1}$, Kone Siaka ${ }^{1}$, Yapi Yapo Magloire ${ }^{2} \&$ Toure Sally $^{3}$ \\ 1 Management and Applied Economics Department, Institute National Polytechnique Houphouët Boigny, \\ Yamoussoukro, Côte d'Ivoire \\ 2 Agriculture and Animal Science Department, Institute National Polytechnique Houphouët Boigny, \\ Yamoussoukro, Côte d'Ivoire \\ 3 College of Agronomy, Agro-economy Section, Institute National Polytechnique Houphouët Boigny, \\ Yamoussoukro, Côte d'Ivoire
}

Correspondence: Noufou Coulibaly, Management and Applied Economics Department, Institute National Polytechnique Houphouët Boigny, Yamoussoukro, Côte d'Ivoire. E-mail: noufou_coulibaly@yahoo.fr

Received: June 17, 2019

doi:10.5539/jas.v12n2p106
Accepted: August 29, $2019 \quad$ Online Published: January 15, 2020

URL: https://doi.org/10.5539/jas.v12n2p106

\begin{abstract}
Cashew was introduced in the north of Côte d'Ivoire to support the economy in the region. This study was conducted to evaluate the technical efficiency of cashew farms in Côte d'Ivoire. The technical efficiency of producers was measured using the Data Envelopment Analysis approach, and the determinants of this efficiency were identified using a TOBIT model. Data were collected in 4 regions: GBEKE, HAMBOL, PORO and WORODOUGOU. In the four regions studied, the average technical efficiency is $49.2 \%$ in Variable Scale Efficiency (VRS) and $38.3 \%$ in Constant Return to Scale (CRS). Based on our results, the producers in the study area were not efficient. The producers who follow the good practices, have a technical coefficient estimated at $74.2 \%$, and superior to those who follow the good practices, of which, the coefficient is estimated at $70.2 \%$, in Variable Scale Efficiency (VRS). The technical efficiency of farms was positively influenced by the age of farms and agricultural advisory services, and negatively influenced by the pruning practice. Income from cashew farming in the study area (21,816 to 37,987 CFAF/person/year according to region) is below extreme poverty line (CFA F 122,385/year/person), leading to deteriorating cashew/food terms of trade. Cashew farming is often used as a means of land appropriation and of getting credit. Its rapid expansion has dramatically reduced land for subsistence agriculture, raising an accute food security issue. Cashew farming has helped improve poverty indicators through macroeconomic policy. However, this impetus from the agricultural sector economy remains insufficient to boost the modernization of the agricultural sector. The country still has all assets (research institutes, schools of agronomy, skills etc.) to reverse this situation. Hence the he study recommends that producers capitalize on exogenous variables which can improve agricultural efficiency. It also recommends coaching organizations to use technical efficiency measurement and identification of effectiveness determinants to better guide their coaching. As for the Government, it should redouble efforts to implement the recommended solutions in order to avoid producer impoverishment, a barrier to harmonious development in this region of Côte d'Ivoire.
\end{abstract}

Keywords: cashew farming, poverty reduction, data envelopment analysis, Côte d'Ivoire

\section{Introduction}

Since independence, Côte d'Ivoire has built its economic development on agriculture. Cashew was introduced for ecological functions (fight against bush fires, land degradation due to deforestation, and the advancing desert) in the northern region of the country in the 1970s. Since 1994, it has played an economic function with an international economic climate conducive to cashew marketing. This new cash crop, first used as a means of diversifying the incomes of northern people in order to fight against poverty, gradually became a substitute for cotton, which was doubly affected by the disintegration of the sector nationwide and by the steady decline in production prices. Production strategy arbitrage between the two cash crops gradually turned in favour of cashew. Today, cashew farming covers just over two-thirds of the country. Production rose from $500 \mathrm{t}$ in 1980 to 711,000 $\mathrm{t}$ in 2018, making Côte d'Ivoire the world's leading producer and exporter of raw nuts ahead of India and 
Vietnam. This increase in cashew nuts production was not without difficulties. Cashew is mainly produced from family farms. The majority of producers usually operate small farms of 2 to 3 ha. Yields are low at 300-350 $\mathrm{kg} / \mathrm{ha}$ vs $1000 \mathrm{~kg} / \mathrm{ha}$ in India (and Guinea Bissau) and up to 2 tonnes in Vietnam. The quality of ivorian nuts is poor. Producers complain not only about poor sale and failure by buyers to comply with the producer price set by the Government, but also about the steady decline in producer prices. However, today the cashew economy is approx 250,000 to 300,000 producers, and 1.5 million direct and indirect jobs. It supports 246 cooperatives, 71 exporting companies, 73 commercial companies and 5 industrialists. Farming income to producers is estimated at 380.650 billion CFAF/year (FIRCA, 2018). All producers living on cashew are hoping for better incomes. The incomes are certainly dependent on the purchase price, but also on farm productivity. A vibrant agricultural sector must necessarily involve maintaining efficient farms, according to Churchill (1979), Wampach (1983), Parsons (1994) and Soegbe Sewade (2010).

Following this performance logic, the Cotton and Cashew Board set up a strategy to disseminate Good Agricultural Practices (GAPs) in order to improve farm yields. Despite the efforts made since 2013, yields are slowly evolving (300 to $500 \mathrm{~kg} / \mathrm{ha}$ ). Producer incomes are still low (CFAF 180,000/farm/year on average) compared to the poverty line of CFAF 269,075/person/year. And this situation has led to a deterioration of cashew/food terms of trade (Kouakou et al., 2017). According to the same author, in 1999, one kilogram of cashew was needed to buy two kilograms of rice. However, in 2013, seven (7) kg of cashew were traded for one kilogram of low quality rice sold at CFAF 350. According to Leibenstein (1978), in economics, the measurement of an entity's performance should take into account the criterion of technical efficiency, which relates the production to the factors of production used. From a scientific perspective, productive or technical efficiency analysis concerns are doubly justified. At the microeconomic level, technical efficiency measurement helps better understand productivity analyses. The same levels of individual efficiency determine collective effectiveness. Achieving efficiency in the economy as a whole therefore requires eliminating individual inefficiencies. The results of efficiency comparisons support decision-making. The position of each producer relative to the most efficient producer in the study provides an insight into the growth potential of productivity. In addition, this analysis provides useful information about the characteristics of production processes. Finally, the analysis helps identify the drivers of performance (Soegbe Sewade, 2010). Technical or productive efficiency growth is the foundation for improving producers' incomes. In fact, producers want to achieve productive efficiency, that is, to produce more without wasting production factors in order to ensure sufficient income for their families.

With a view to enhancing technical efficiency on cashew farms in Côte d'Ivoire, the Coton and Cashew Board (CCB) commissioned this study in four (4) regions: GBEKE, HAMBOL, PORO, and WORODOUGOU. The overall objective of the study was to assess the impact of the CCB on cashew producers. Specifically, it was to measure and compare the technical efficiency of producers who follow good practice and those who do not, identify the drivers of technical efficiency, and analyze the poverty situation of such producers in order to make recommendations to improve their technical efficiency.

\section{Literature Review}

\subsection{Adoption of Technological Innovations and Socio-Economic Impact of Cashew Farming on Producers}

Several studies were conducted on the analysis of farm efficiency, the adoption of technological innovations and the socio-economic impact of cashew farming on producers. Benido (2017) affirmed that there are several models to analyze the determinants of adopting good agricultural practices in cashew farming. And that the most widespread are: Tobit, Logit and Probit. However, he chose the Probit model, which is better suited to dichotomous and qualitative dependent variables. He pointed out that the determinants of adopting good practices are: the level of education of householders, the price earned from the sale of nuts, and membership of a functional producer organization. Balogoun et al. (2014) used the COBB-DOUGLAS economic profitability model to identify determinants of the annual income earned from the sale of cashew nuts. According to the author, this income is significantly influenced by the area planted, the total cost of labor, the yield of nuts, the selling price per kilogram of nuts, the producer's marital status, and access to credit. The income generated by this crop helps producers meet their needs, improve their living conditions and environment, and especially increase schooling rate. However, the development of cashew farming leads to many farmer/pastoralist conflicts and land conflicts that threaten social cohesion in the northern area of the country. Kouakou et al. (2017) confirm the predominance of cashew farming in the northern area (Bondoukou department). The emergence of cashew farming raises a serious food security problem because of scarcity of land and labor for subsistence agriculture. For this author, even though cashew farming provides income for producers, this is very low and cannot buy food to meet needs. 
To understand all these failures, Stessens (2002) argues that for an innovation or production technique to be successfully adopted, it is essential to study the production system in the area. This would help better understand producer constraints (land pressure, priority, availability of labor, lack of financial resources or credit etc.) and accurately assess the conditions for adopting new technologies. To the same author, most of the agricultural development projects that operated in northern Côte d'Ivoire targeted a specific crop or aspect of the farm, neglecting the entierety and specificity of the farm and its socio-economic environment. These projects often failed to address the real and critical problems of the target groups. According to Roca (1987), the list of failed projects in sub-Saharan Africa is much longer than that of successful projects. Fresco (1986) in his "Cassava in Shifting Cultivation" reached a similar conclusion. Apart from cotton farming and the localized adoption of animal traction, no other innovation was really successful in northern Côte d'Ivoire from 1962 to 1980 (Bigot, 1981). Surveys of the adoption of new varieties of maize, sorghum and millet in the regions of Ferkessédougou and Sinématiali in northern Côte d'Ivoire reveal similar results. Beets (1990) confirms this with special emphasis on the need for a thorough analysis of the farming practices, the socio-cultural system and the economics of farming systems before any intervention. Without comprehensive information on farming systems, it is highly doubtful that new techniques will be adopted by farmers because they are faced with a myriad of factors that they need to consider when making any production decision. Population density, and market access and economic profitability of farms are, inter alia, the main factors determining the evolution of production systems and, consequently, the adoption of agricultural innovations. According to Boserup (1965), until certain conditions for these two factors are unmet, production systems are likely to remain unchanged. Finally, the low rate of adoption of new varieties or crops and the improved techniques developed at research stations have reinforced the conviction that an in-depth study of the technical efficiency of farms and of the determinants of their effectiveness is essential before any intervention. This study would therefore provide answers for the profitability of cashew farms and their impact in the fight against poverty, based on the mathematical optimization tools coupled with the econometric model presented in the section below.

\subsection{Technical Efficiency}

The concept of technical efficiency has its origin in fundamental theoretical work on the behavior of firms by Debreu (1951), Koopmans (1951), and Farrell (1957). Efficiency is intended to gauge the ability of a production system to produce "at best" through the implementation of all means of production (capital, land and labor) (Coelli et al., 1998). Berger Allen and Humphrey David (1997) show that there are two main families of competing methods in the way of constructing the frontier and therefore in calculating the technical efficiencies: parametric methods and non-parametric methods. The choice between the two methods is purely optional and depends on the researcher. In the nonparametric approach, no particular analytical form is specified for the boundary, but rather the formal properties that the whole of production is supposed to respect. The non-convex non-parametric approach was proposed by Deprins et al. (1984) with the only assumption being the free disposal of productions and inputs. The convex non-parametric frontier approach was introduced by Farrell (1957) through the Data Envelopment Analysis (DEA) method. This data wrapping method was first developed by Charnes, Cooper, and Rhodes (1978) who generated the CCR model (Constant Return to Scale Model), and then by Banker, Charnes, and Cooper (1984), who produced the BCC model (Variable return to scale model). This method involves the use of linear programming techniques. The Data Envelopment Analysis (DEA) method, according to Huguenin (2013), makes it possible to evaluate the performance of organizations that turn resources (inputs) into services (outputs), and more easily takes into account multi-production technology. It helps consider several outputs and inputs at the same time, and then determines the frontier at the top of observations rather than a regression plan at their center. Calculating an efficiency score indicates whether an organization has room for improvement. By identifying the return to scale type, whether variable (BCC or Variable Return to Scale model) or constant (CCR or Constant Return to Scale model), it indicates whether an organization should increase or reduce its size to minimize its average cost of production. By setting target values (input or output orientation), it indicates by how much the inputs need to be reduced and the outputs increased for an organization to become efficient. By identifying reference pairs, the Data Envelopment Analysis (DEA) method indicates which organizations have "best practices" to be analyzed. For our part, we are interested in the BCC model. In the model developed by Banker et al. (1984), the amount of outputs produced can be maximised without the need to increase inputs. The BCC model uses the following mathematical program:

$$
\begin{gathered}
\operatorname{Max} \mathrm{h}(\mathrm{k})=\sum_{\mathrm{r}=1}^{\mathrm{s}} \mathrm{U}_{\mathrm{r}} \cdot \mathrm{Y}_{\mathrm{r}} \cdot \mathrm{k}+\mathrm{C}_{\mathrm{k}} \text { under constraint, } \\
\left\{\begin{array}{c}
\sum_{\mathrm{i}=1}^{\mathrm{m}} \mathrm{V}_{\mathrm{i}} \cdot \mathrm{X}_{\mathrm{i}} \cdot \mathrm{k}=1 \\
\sum_{\mathrm{r}=1}^{\mathrm{s}} \mathrm{U}_{\mathrm{r}} \cdot \mathrm{Y}_{\mathrm{r}} \cdot \mathrm{j}-\sum_{\mathrm{i}=1}^{\mathrm{m}} \mathrm{V}_{\mathrm{i}} \cdot \mathrm{X}_{\mathrm{i}} \cdot \mathrm{k}-\mathrm{C}_{0} \leq 0 \\
\mathrm{U}_{\mathrm{r}}, \mathrm{U}_{\mathrm{i}} \geq \varepsilon
\end{array}\right.
\end{gathered}
$$


Where, $s=$ number of outputs; $U_{r}=$ weighting coefficient for output $r ; Y_{r}=$ amount of output $r$ produced by the firm; $m$ = number of inputs; $U_{i}=$ weighting coefficient for inputs $i ; X_{i}=$ amount of input $i$ used by the firm.

In short, the nonparametric method has the characteristics of being more flexible and makes it possible to avoid errors due to the poor choice of the function. However, it attributes all the inefficiency to the producer without taking into account other random factors beyond the control of the operator, which may be sources of inefficiency. Several studies have been conducted on technical efficiency.

Kane (2010) used the nonparametric Data Envelopment Analysis (DEA) method to measure the effectiveness of family farms in the Zoetelé, and a censored TOBIT to generate and identify the efficiency factors of family farms. The results show that the technical efficiency levels of family farms are estimated at $44.6 \%$ in constant returns to scale and at $67.8 \%$ in variable returns to scale. In addition, the area under cultivation and the destination of the production negatively affect the technical efficiency while membership of a peasant organization and age improve it. Djimasra (2010) measured the technical efficiency of 38 cotton-producing countries over a period from 1990 to 2008, or 1026 observations in total, using the Data Envelopment Analysis (DEA) method of the non-parametric model. The efficiency scores obtained under the Constant Return to Scale (CRS) and Variable Return to Scale (VRS) technologies are $51.9 \%$ and $73.7 \%$ respectively on average. Koné (2015) also used the non-parametric Data Envelopment Analysis (DEA) method for his analysis of the poverty and technical efficiency of cocoa producers of the Méné agricultural cooperative company. His results show that the technical efficiency for cooperative members is $33 \%$ compared with $82 \%$ for non-cooperative members. The cooperative members are therefore less efficient.

\subsection{Analysis of Determinants of Technical Efficiency}

Determinants are factors that have a positive or negative impact on a phenomenon to be studied. An analysis of the determinants of effectiveness uses several methods: correlation analysis, average-to-average method, variance analysis, and regression analysis, on which we will focus. Regression analysis is a method of performing regressions of efficiency indices on a number of technical or socio-economic variables. A two-step approach has been suggested (Tobin, 1958). It determines efficiency indices through discretionary variables in the production function firstly, and secondly, uses non-discretionary variables to explain efficiency. Here, two estimation methods are used: the ordinary least squares method (OLS) and the double truncation TOBIT method. Initiated by Tobin (1958), the Tobit model originated from his work modeling the relationship between a household's income and spending on durable goods. It generally refers to regression models in which the definition domain of the dependent variable is constrained in one form or another. It is a limited dependent variable model, that is, a model for which the dependent variable is continuous, but is only observable over a certain interval. It lies midway between the linear regression models where the endogenous variable is continuous and observable, and the qualitative models. To estimate the Tobit, the ordinary least squares method or the maximum likelihood method can be used. The Tobit model is as follows:

$$
\mathrm{E}_{\mathrm{i}}=\mathrm{g}\left(\chi_{\mathrm{i}}\right)=\beta_{0}+\sum_{\mathrm{i}=1}^{\mathrm{n}} \beta_{\mathrm{i}} \chi_{\mathrm{i}}+\lambda_{\mathrm{i}}
$$

Where, $E_{i}$ is the technical efficiency index; $\chi_{\mathrm{i}}$ are the technical and socioeconomic characteristics of producers; $\lambda_{\mathrm{i}}$ is the random term; $\beta$ is the weight associated with each technical or socio-economic variable.

The model will be estimated using the maximum likelihood method, given the specificity of the dependent variable:

$$
\mathrm{Y}_{\mathrm{i}}^{*}=\beta \chi_{\mathrm{i}}+\lambda_{\mathrm{i}}
$$

Where, $Y_{i}^{*}$ is the efficiency score for each producer; $i=\{1, n\}$ is the producer index.

The use of the TOBIT model for the analysis of determinants has shown that cocoa farming as main activity, acquiring land by inheritance or gift, marital status, producer age, and farm age impact technical efficiency positively. Ndiaye (2018) analyzed the technical efficiency of family farms in Mauritius. The nonparametric Data Envelopment Analysis (DEA) approach and the TOBIT model were used to measure effectiveness and identify its determinants. The results showed that the average technical efficiency under the variable scale yield is $72.6 \%$ and that $46.5 \%$ of the sample are technically efficient under variable scale yield. As for productivity, it is significantly influenced by farmer sex, cultivated area, and salary.

\subsection{Poverty Analysis}

According to Eddy (2017), the farming income represents what the farm provides to the producer for his work, his land and his management. It is the result from the difference between the gross product in value (GP) and the actual costs (AC) consisting of fixed costs (CF) and average variable costs (VC). The farming income is 
therefore: $\mathrm{FI}(\mathrm{CFA} \mathrm{F})=\mathrm{GP}-\mathrm{AC}=\mathrm{GP}-(\mathrm{VC}+\mathrm{FC})$. If the farming income is positive, then it can be concluded that the activity is economically profitable. However, if the result is negative, then the activity is said to be not economically profitable. This happens when the total costs are too high and the gross product is too low to cover them. According to Paraïso et al. (2010), very high fixed costs may make the farming income negative in the case of large investments. This indicator is also used to measure business performance, called value added. The farming income will be compared to the poverty line to assess the farmer's poverty level.

\section{Methodology}

\subsection{Study Area and Sampling}

The data were collected in four (4) regions of the country, the characteristics of which are summarized in Table 1: Poro in the north; Worodougou in the north-west; and GBêkê and Hambole in the center. The data in our study were from the 2017-2018 season. The four regions have a wet tropical climate as a whole. Rainfall is low in this area; soils are rich but very fragile. Poverty remains high (over 50\%). The economy is mainly agricultural and pastoral.

Table 1. The characteristics of the four regions

\begin{tabular}{|c|c|c|c|c|c|}
\hline \multicolumn{2}{|c|}{ Characteristics/Regions } & \multirow{2}{*}{$\begin{array}{l}\text { PORO } \\
\text { High plateaus at } 360 \mathrm{~m} \\
\text { altitude }\end{array}$} & \multirow{2}{*}{$\begin{array}{l}\text { WORODOUGOU } \\
\text { Hight plateaus at } 350 \mathrm{~m} \\
\text { altitude }\end{array}$} & \multirow{2}{*}{$\begin{array}{l}\text { GBEKE } \\
\text { Altitude } 339 \text { metres }\end{array}$} & \multirow{2}{*}{$\begin{array}{l}\text { HAMBOL } \\
\text { Altitude } 326 \text { metres }\end{array}$} \\
\hline Bio-physical & Relief & & & & \\
\hline & Rainfall & 1,200 and $1,400 \mathrm{~mm}$ & $1,286 \mathrm{~mm} /$ year & $1,139 \mathrm{~mm} /$ year & $1,087 \mathrm{~mm} /$ year \\
\hline & Soil & $\begin{array}{l}\text { Medium or poorly } \\
\text { desaturated ferralitic soils }\end{array}$ & $\begin{array}{l}\text { Poorly desaturated ferralitic } \\
\text { soils. Tropical brown soils. } \\
\text { Good farmlands }\end{array}$ & $\begin{array}{l}\text { Medium or poorly } \\
\text { desaturated ferralitic soils }\end{array}$ & $\begin{array}{l}\text { Ferruginous soil over } \\
\text { ferrallitic material }\end{array}$ \\
\hline & Climate & Humid tropical climate type & Sudanese type climate & Tropical type climate & Sudanese type climate \\
\hline & Vegetation & $\begin{array}{l}\text { Grassy savannah with trees } \\
\text { and gallery forests and } \\
\text { clear forests }\end{array}$ & $\begin{array}{l}\text { Wooded savannah and dry } \\
\text { clear forests }\end{array}$ & $\begin{array}{l}\text { Grassy savannah and } \\
\text { some gallery forests }\end{array}$ & $\begin{array}{l}\text { Grassy savannah and } \\
\text { some gallery forests }\end{array}$ \\
\hline & Area & $12,621 \mathrm{Km}^{2}$ & $11,492 \mathrm{Km}^{2}$ & $8,930 \mathrm{Km}^{2}$ & $19,497 \mathrm{Km}^{2}$ \\
\hline \multirow[t]{6}{*}{ Human } & Ethnicities & Sénoufo, Dioula, Malinké & Mandé, Sénoufo, Gouro & Baoulé, Malinké & Tagbana, Djimini \\
\hline & Population & 763,852 & 272,334 & 940,623 & 430,000 \\
\hline & Religion & -Muslim (54\%) & -Muslim (72\%) & -Muslim (37\%) & -Muslim (24\%) \\
\hline & & -Animist (16\%) & -Animist $(10 \%)$ & -Animist (23\%) & -Animist (26\%) \\
\hline & & -Christian (9\%) & -Christian (5\%) & -Christian (21\%) & -Christian (30\%) \\
\hline & & -No religion $(20 \%)$ & -No religion $(12 \%)$ & -No religion $(15 \%)$ & -No religion $(20 \%)$ \\
\hline \multirow[t]{2}{*}{ Economic } & Activities & $\begin{array}{l}\text { Cereals, yam, cassava, } \\
\text { market gardening, cotton, } \\
\text { cashew, livestock farming, } \\
\text { tourism }\end{array}$ & $\begin{array}{l}\text { Sweet potato, cereals, coffee } \\
\& \text { cocoa, cashew, cotton, } \\
\text { cassava, banana, livestock } \\
\text { farming, trade, mining }\end{array}$ & $\begin{array}{l}\text { Yam, banana, market } \\
\text { gardening, cashew, trade, } \\
\text { mangoe, citrus fruit, } \\
\text { industry }\end{array}$ & $\begin{array}{l}\text { Yam, cereals, cashew, } \\
\text { livestock farming, } \\
\text { trade, honey, pottery }\end{array}$ \\
\hline & Poverty rate & $54.0 \%$ & $54.5 \%$ & $54.9 \%$ & $56.1 \%$ \\
\hline
\end{tabular}

Source: Ministère du Plan et Dévelppement, Rep. Côte d'Ivoire, 2015.

To determine the sample, we used the following Bernoulli formula:

$$
\mathrm{n}=\mathrm{t}^{2} \times \mathrm{p} \times(1-\mathrm{p}) / \mathrm{m}^{2}
$$

Where, n: Minimum sample size to get significant results for an event and a set risk level; $t$ : Confidence level (the standard value for the confidence level of $95 \%$ will be 1.96); $\mathrm{p}$ : The estimated share of population presenting the characteristic estimated at $11.8 \%$, resulting from the producers in study area/number of national cashew producers ratio (35415/300000); m: Error margin (usually set at 5\%).

The size of our sample was estimated at 160 farms. The farms were selected randomly in the area concerned by the snowball approach, taking into account farmer availability and farm accessibility. A correlation test was performed to analyze the endogeneity. The distribution of our sample is shown in the Table 2. 
Table 2. Distribution of our sample

\begin{tabular}{llll}
\hline Regions & Towns & Size & Total \\
\hline PORO & Korhogo & 20 & 40 \\
& Napié & 20 & \\
\hline WORODOUDOU & Séguéla & 20 & \\
& Djibrosso & 10 & \\
& Sifié - Worofla & 10 & 40 \\
\hline GBEKE & Bouaké & 15 & \\
& Béoumi & 15 & 40 \\
\hline HAMBOL & Bottro & 10 & \\
\hline Total & Dabakala & 8 & $\mathbf{1 6 0}$ \\
\hline
\end{tabular}

\subsection{Tools and Method}

\subsubsection{Classification of Producers}

The producers in our sample were classified into three (3) groups (low, medium and high) according to the intensity of implementation of Good Agricultural Practices (GAPs), depending on the farmer coaching organization. The practices include cleaning, fireguard, pruning, thinning, insecticide use and on-farm herbicide use. The score method is used here:

(i) We start by assigning a coefficient $(1=$ yes, $0=$ no) of implementation to each GAP because we expect an impact on the one who implements the GAPs.

(ii) Then, we calculate the average score obtained by each producer based on the formula:

$$
\text { Average Score }=\frac{\sum \text { score i }}{\mathrm{N}}
$$

Where, $\mathrm{N}$ is the number of practices considered.

(iii) Thereafter, we calculate a producer implementation rate, based on the following formula:

$$
\text { ProdRate }=\frac{\sum_{\mathrm{i}}^{\mathrm{n}} \text { score } \mathrm{i}}{\text { maximum total score }}
$$

(iv) And, we calculate the average rate (AvRate) and the deviation for the rates obtained.

At the end of these stages, producers are ranked according to the rate obtained based on the following criterion:

Weak implementation: ProdRate $\leq$ (AvRate - Standard Deviation).

Average implementation: (AvRate - Standard Deviation) $\leq$ ProdRate $<$ AvRate.

Strong implementation: ProdRate $\geq$ AvRate.

It was after this classification that the statistics for the different classes were extracted, and the efficiency calculated depending on classes.

\subsubsection{Measuring Technical Efficiency}

As part of this study, we chose Data Envelopment Analysis (DEA) in output-oriented variable return of scale (VRS-model) as a tool for measuring technical efficiency. This non-parametric convex method seems to us to be better suited for reasons of flexibility and the most widely used tool for calculating efficiency frontier and determining efficiency scores. The dependent variable or output is the Production (P) expressed in kilograms $(\mathrm{Kg})$. The explanatory variables or inputs are as follows:

Land (T): This is cashew farmed area. It is expressed in hectare (ha).

Capital (K): These are the annual quantities of inputs, fixed costs and variable costs. The inputs taken into account are fertilizers, insecticides and herbicides. Fixed costs consist of equipment amortization. Variable costs consist of small agricultural equipment, transport costs, ancillary expenses (fuel, string), bags purchased and casual labor. Capital is expressed in value (CFA Francs). 
Work (W): It consists of hired labor and family labor. It is expressed in man day (m-d).

(i) The Constant Return to Scale Model (CCR Model) is as follows:

Developed by Charnes et al. (1978), this model is input-oriented and assumes constant returns to scale. Thus, for each unit $\mathrm{k}$, the equation amounts to maximizing the "efficiency ratio" in the presence of "s" outputs and " $\mathrm{m}$ " inputs. This equation can be reduced to a simplified expression of linear programming, as follows:

$$
\operatorname{Max} h(k)=\sum_{r=1}^{\mathrm{s}} \mathrm{U}_{\mathrm{r}} \cdot \mathrm{Y}_{\mathrm{r}} \cdot \mathrm{k}+\mathrm{C}_{\mathrm{k}}
$$

Under constraint,

$$
\left\{\begin{array}{c}
\sum_{\mathrm{i}=1}^{\mathrm{m}} \mathrm{V}_{\mathrm{i}} \cdot \mathrm{X}_{\mathrm{i}} \cdot \mathrm{k}=1 \\
\sum_{\mathrm{r}=1}^{\mathrm{s}} \mathrm{U}_{\mathrm{r}} \cdot \mathrm{Y}_{\mathrm{r}} \cdot \mathrm{j}-\sum_{\mathrm{i}=1}^{\mathrm{m}} \mathrm{V}_{\mathrm{i}} \cdot \mathrm{X}_{\mathrm{i}} \cdot \mathrm{k}-\mathrm{C}_{0} \leq 0 \\
\mathrm{U}_{\mathrm{r}}, \mathrm{U}_{\mathrm{i}} \geq \varepsilon
\end{array}\right.
$$

Reciprocally, the CCR model may be estimated as a minimisation of the cost function. We would obtain:

$$
\text { Min } \mathrm{f}(\mathrm{k})=\frac{\sum_{\mathrm{i}=1}^{\mathrm{m}} \mathrm{U}_{\mathrm{i}} \cdot \mathrm{X}_{\mathrm{r}} \cdot \mathrm{k}}{\sum_{\mathrm{r}=1}^{\mathrm{s}} \mathrm{U}_{\mathrm{r}} \cdot \mathrm{Y}_{\mathrm{r}} \cdot \mathrm{k}}, \text { under constraints, }\left\{\begin{array}{l}
\frac{\sum_{\mathrm{i}=1}^{\mathrm{m}} \mathrm{U}_{\mathrm{i}} \cdot \mathrm{X}_{\mathrm{r}} \cdot \mathrm{k}}{\sum_{\mathrm{r}=1}^{\mathrm{s}} \mathrm{U}_{\mathrm{r}} \cdot \mathrm{r}^{\prime} \cdot \mathrm{k}} \leq \mathrm{j}=\ldots \mathrm{n} \text { (number of units) } \\
\mathrm{V}_{\mathrm{r}}, \mathrm{U}_{\mathrm{i}} \geq 0
\end{array}\right.
$$

(ii) Variable return to scale model (BCC):

The BCC model by Banker et al. (1984) relates to variable returns to scale. It introduces new variables into the CCR model, which distinguishes between scale efficiency and technical efficiency. The formulation of the model is as follows:

$$
\operatorname{Max} h(k)=\sum_{r=1}^{s} U_{r} \cdot Y_{r} \cdot k+C_{k}
$$

Under constraint,

$$
\left\{\begin{array}{c}
\sum_{\mathrm{i}=1}^{\mathrm{m}} \mathrm{V}_{\mathrm{i}} \cdot \mathrm{X}_{\mathrm{i}} \cdot \mathrm{k}=1 \\
\sum_{\mathrm{r}=1}^{\mathrm{s}} \mathrm{U}_{\mathrm{r}} \cdot \mathrm{Y}_{\mathrm{r}} \cdot \mathrm{j}-\sum_{\mathrm{i}=1}^{\mathrm{m}} \mathrm{V}_{\mathrm{i}} \cdot \mathrm{X}_{\mathrm{i}} \cdot \mathrm{k}-\mathrm{C}_{0} \leq 0 \\
\mathrm{U}_{\mathrm{r}}, \mathrm{U}_{\mathrm{i}} \geq \varepsilon
\end{array}\right.
$$

Technical efficiency will be measured by region and by class of producers.

3.2.3 Analysis of Determinants of Technical Efficiency

The analysis of the determinants of producer technical efficiency was made by the TOBIT model. We chose this model as it is better suited for discrete dependent variables in qualitative determinants analysis. Efficiency is considered a limited dependent variable with values between 0 and 1 . The model's explanatory variables are compiled in Table 3. 
Table 3. Explanatory variables for the analysis of determinants of the TOBIT model

\begin{tabular}{|c|c|c|}
\hline Variables & Explanation, Type of variable, and Codification & Sign expected \\
\hline Area (Area) & Producers with a small acreage are more efficient than those with a larger acreage. & $+/-$ \\
\hline Farm age (Farm_Age) & $\begin{array}{l}\text { Farm age will affect productivity at two levels: firstly, a young ( }-3 \text { years old) or old ( }+25 \text { years } \\
\text { old) farm will have a low yield, unlike a farm that falls within this interval if the producer } \\
\text { follows good farming practices. To take into account the age effect, we used the square shape of } \\
\text { age. Indeed, Miyata et al., quoted by Eddy }(2017) \text {, state that the relation between farmer's age } \\
\text { and technical efficiency is U-shaped. We think it is the same for the age of the farm. }\end{array}$ & $+/-$ \\
\hline $\begin{array}{l}\text { Creation and } \\
\text { maintenance of } \\
\text { fireguard (Fireguard) }\end{array}$ & $\begin{array}{l}\text { Fireguard helps protect the farm from bushfires that destroy the hard work of producers. This } \\
\text { has a positive impact on efficiency. } \\
\text { Codification: } \mathbf{1}=\text { Yes; } \mathbf{0}=\text { No }\end{array}$ & + \\
\hline Thinning (Thinning) & $\begin{array}{l}\text { It helps respect the } 10 \mathrm{~m} \text { space recommended as distance between the trees and fosters sound } \\
\text { development of the crown. Which improves its productivity and positively impacts its } \\
\text { efficiency. } \\
\text { Codification: } \mathbf{1}=\text { Yes; } \mathbf{0}=\text { No }\end{array}$ & + \\
\hline Pruning (Pruning) & $\begin{array}{l}\text { Pruning involves cutting large branches that are cumbersome, diseased or dead to improve } \\
\text { productivity. This has a positive impact on efficiency. } \\
\text { Codification: } \mathbf{1}=\text { Yes; } \mathbf{0}=\text { No }\end{array}$ & + \\
\hline Clearing (Clearing) & $\begin{array}{l}\text { Proper maintenance of the farm by clearing (weeding) it frequently provides a better } \\
\text { production. Clearing positively affects producer efficiency. } \\
\text { Codification: } \mathbf{1}=\text { Yes; } \mathbf{0}=\text { No }\end{array}$ & + \\
\hline $\begin{array}{l}\text { Educational level } \\
\text { (Educ_Level) }\end{array}$ & $\begin{array}{l}\text { The more educated the producer, the better he understands training and is able to implement } \\
\text { modern production techniques. He also has the opportunity to get necessary information on } \\
\text { market prices and buy his inputs at a lower price. This has a positive impact on efficiency. } \\
\text { Codification: } \mathbf{1}=\text { Yes; } \mathbf{0}=\text { No }\end{array}$ & + \\
\hline $\begin{array}{l}\text { Dedicated agricultural } \\
\text { advisory service } \\
\text { (Agri Advisory) }\end{array}$ & $\begin{array}{l}\text { Dedicated agricultural advisory service includes several activities including training and } \\
\text { awareness. It aims to improve producers' income and yields. This has a positive impact on } \\
\text { efficiency. } \\
\text { Codification: } \mathbf{1}=\text { Yes; } \mathbf{0}=\text { No }\end{array}$ & + \\
\hline $\operatorname{Sex}(\operatorname{Sex})$ & $\begin{array}{l}\text { Men have more physical strength to endure cultivation work. This has a positive impact on their } \\
\text { effectiveness. } \\
\text { Codification: } \mathbf{1}=\text { Yes; } \mathbf{0}=\text { No }\end{array}$ & + \\
\hline Experience (Experience) & $\begin{array}{l}\text { Technical efficiency is } U \text { shaped. The yound and oldest producers are supposed to be less } \\
\text { efficient whilst those in the interval are more efficient. }\end{array}$ & $+/-$ \\
\hline
\end{tabular}

The model is as follows:

$$
\begin{aligned}
\mathrm{Y}^{*}= & \mathrm{a} 1 \cdot \text { Area }+\mathrm{a} 2 \cdot \text { Farm_Age }+\mathrm{a} 3 \cdot \text { Thinning }+\mathrm{a} 4 \cdot \text { Fireguard }+\mathrm{a} 5 \cdot \text { Pruning }+\mathrm{a} 6 \cdot \text { Educ_Level }+ \\
& \mathrm{a} 7 \cdot \operatorname{Sex}+\mathrm{a} \cdot \text { Agri_Advisory }+\mathrm{a} 9 \cdot \text { Clearing }+\mathrm{a} 10 \cdot \text { Experience }+\mathrm{e}
\end{aligned}
$$

Where, $\mathrm{Y}^{*}$ : explained variable i.e., producer efficiency index; ai: estimated coefficients whose sign indicates the meaning of the correlation between the explanatory variable and the explained variable, with $\mathrm{i}=\{1,10\}$; e: error term.

\subsubsection{Analysis of Poverty}

Farm incomes by region will be estimated, and compared with poverty benchmark in Côte d'Ivoire. The indicator used is as follows:

$$
\text { FI }(\text { CFA F })=\mathrm{GP}-\mathrm{AC}=\mathrm{GP}-(\mathrm{VC}+\mathrm{FC})
$$

Where, FI is farming income; GP is gross product in value; $\mathrm{AC}$ is actual costs; $\mathrm{CF}$ is fixed costs; and VC is variable costs.

\section{Results and Discussions}

\subsection{Characterisation of the Study Area}

The population is $60 \%$ young (under 25 years old), and women - $49.6 \%$ of the population - are predominantly in the vegetable and food crop trade. Cashew farming is a householder and male-dominated business. However, it involves $13 \%$ of women. Family size is 8 people on average in the Poro and Worodougou, and 6 people in Gbêkê and Hambol. The illiteracy rate among adults is $56.8 \%$ in Gbêkê and Hambol; $78.8 \%$ in Poro; and $72 \%$ in Worodougou. Funding and agricultural supervision are almost non-existent in the study area. 


\subsection{Measurement of Producer Technical Efficiency by Region}

Data compiled in Table 4 show that the annual production per farm ranges from 50 to $9,200 \mathrm{~kg}$; farm area ranges from 0.50 ha to 32 ha; annual capital from 12,000 to 1,981,500 CFA Francs; and annual work from 10 to 1,500 m-d.

Table 4. General statistics of DEA variables by region

\begin{tabular}{|c|c|c|c|c|c|}
\hline Regions/Varibles & & Production (kg) & Land (ha) & Capital (CFAF) & Work (m-d) \\
\hline \multirow{4}{*}{$\operatorname{GBEKE}(\mathrm{N}=40)$} & Minimum & 50 & 0.50 & 14500 & 10 \\
\hline & Average & 1609 & 3.42 & 261935 & 298 \\
\hline & Maximum & 6000 & 12.00 & 1270667 & 1320 \\
\hline & Standard Deviation & 1299 & 2.73 & 246251 & 232 \\
\hline \multirow{4}{*}{ HAMBOL $(N=40)$} & Minimum & 50 & 1.00 & 12000 & 36 \\
\hline & Average & 1781 & 5.87 & 255765 & 249 \\
\hline & Maximum & 7000 & 22.00 & 910000 & 659 \\
\hline & Standard Deviation & 1521 & 4.83 & 209744 & 144 \\
\hline \multirow{4}{*}{$\operatorname{PORO}(\mathrm{N}=40)$} & Minimum & 150 & 0.50 & 28300 & 78 \\
\hline & Average & 1991 & 5.79 & 268269 & 402 \\
\hline & Maximum & 7000 & 26.00 & 1981500 & 1505 \\
\hline & Standard Deviation & 1631 & 6.00 & 340928 & 276 \\
\hline \multirow{4}{*}{ WORODOUGOU $(N=40)$} & Minimum & 150 & 1.00 & 30000 & 22 \\
\hline & Average & 2053 & 6.28 & 269836 & 211 \\
\hline & Maximum & 9200 & 32.00 & 1671667 & 894 \\
\hline & Standard Deviation & 1879 & 7.10 & 346250 & 223 \\
\hline
\end{tabular}

Over the entire study area (Table 5), the analysis shows that, on average, farmers produce $1,859 \mathrm{Kg}$; the average farming area is 5.34 ha; producers' capital is 263,951 CFA Francs; working time is $290 \mathrm{~m}$-d. The standard deviations are high, illustrating a great variability of farm models.

Table 5. Statistics of DEA variables

\begin{tabular}{llllll}
\hline & & Production (kg) & Land (ha) & Capital (CFAF) & Work (m-d) \\
\hline & Minimum & 50 & 0.50 & 12000 & 10 \\
Total Sample N= 160 & Average & 1859 & $\mathbf{5 . 3 4}$ & $\mathbf{2 6 3 9 5 1}$ & 290 \\
& Maximum & 9200 & 32.00 & 1981500 & 1505 \\
& Standard Deviation & 1591 & 5.48 & 289158 & 233 \\
\hline
\end{tabular}

To understand the endogeneity, a correlation test was run, and the results are presented in Table 6.

Table 6. Correlation matrix (Pearson)

\begin{tabular}{lllll}
\hline Variables & Production & Land & Capital & Work \\
\hline Production & 1 & 0.523 & 0.262 & 0.277 \\
Land & 0.523 & 1 & 0.481 & 0.245 \\
Capital & 0.262 & 0.481 & 1 & 0.211 \\
Work & 0.277 & 0.245 & 0.211 & 1 \\
\hline
\end{tabular}

The Pearson correlation test shows that the correlation coefficients observed between variables are very different from 1. The variables are therefore not correlated with each other, and there is no endogeneity between the variables of our DEA model. Selection biases were treated by randomization. People surveyed were selected randomly in the area concerned by the snowball approach, taking into account their availability, accessibility and willingness to contribute to the study. And the results are shown in Table 7. 
Table 7. General statistics of DEA variables over total sample

\begin{tabular}{|c|c|c|c|c|c|c|c|c|c|}
\hline NUM & Codprod & REGION & CRSTE & VRSTE & NUM & Codprod & REGION & CRSTE & VRSTE \\
\hline 1 & Prod1 & GBEKE & 0.305 & 0.487 & 81 & Prod81 & PORO & 0.500 & 0.469 \\
\hline 2 & Prod2 & GBEKE & 0.416 & 0.421 & 82 & Prod82 & PORO & 0.386 & 0.469 \\
\hline 3 & Prod3 & GBEKE & 0.386 & 0.445 & 83 & Prod83 & PORO & 0.386 & 0.468 \\
\hline 4 & Prod4 & GBEKE & 0.386 & 0.923 & 84 & Prod84 & PORO & 0.500 & 0.468 \\
\hline 5 & Prod5 & GBEKE & 0.500 & 0.857 & 85 & Prod85 & PORO & 0.386 & 0.467 \\
\hline 6 & Prod6 & GBEKE & 0.072 & 0.762 & 86 & Prod86 & PORO & 0.316 & 0.467 \\
\hline 7 & Prod7 & GBEKE & 0.386 & 0.745 & 87 & Prod87 & PORO & 0.236 & 0.467 \\
\hline 8 & Prod8 & GBEKE & 0.386 & 0.723 & 88 & Prod88 & PORO & 0.500 & 0.467 \\
\hline 9 & Prod9 & GBEKE & 0.386 & 0.721 & 89 & Prod89 & PORO & 0.386 & 0.465 \\
\hline 10 & Prod 10 & GBEKE & 0.386 & 0.859 & 90 & Prod90 & PORO & 0.386 & 0.465 \\
\hline 11 & Prod11 & GBEKE & 0.386 & 0.843 & 91 & Prod91 & PORO & 0.386 & 0.463 \\
\hline 12 & Prod12 & GBEKE & 0.386 & 0.843 & 92 & Prod92 & PORO & 0.386 & 0.462 \\
\hline 13 & Prod13 & GBEKE & 0.386 & 0.843 & 93 & Prod93 & PORO & 0.386 & 0.462 \\
\hline 14 & Prod14 & GBEKE & 0.100 & 0.578 & 94 & Prod94 & PORO & 0.386 & 0.459 \\
\hline 15 & Prod15 & GBEKE & 0.386 & 0.663 & 95 & Prod95 & PORO & 0.386 & 0.459 \\
\hline 16 & Prod 16 & GBEKE & 0.500 & 0.659 & 96 & Prod96 & PORO & 0.386 & 0.459 \\
\hline 17 & Prod17 & GBEKE & 0.386 & 0.659 & 97 & Prod97 & PORO & 0.386 & 0.459 \\
\hline 18 & Prod18 & GBEKE & 0.386 & 0.656 & 98 & Prod98 & PORO & 0.386 & 0.457 \\
\hline 19 & Prod19 & GBEKE & 0.386 & 0.520 & 99 & Prod99 & PORO & 0.386 & 0.457 \\
\hline 20 & Prod 20 & GBEKE & 0.200 & 0.519 & 100 & Prod100 & PORO & 0.386 & 0.455 \\
\hline 21 & Prod 21 & GBEKE & 0.500 & 0.510 & 101 & Prod101 & PORO & 0.386 & 0.454 \\
\hline 22 & Prod 22 & GBEKE & 0.386 & 0.495 & 102 & Prod102 & PORO & 0.386 & 0.452 \\
\hline 23 & Prod 23 & GBEKE & 0.167 & 0.492 & 103 & Prod103 & PORO & 0.386 & 0.449 \\
\hline 24 & Prod 24 & GBEKE & 0.386 & 0.493 & 104 & Prod104 & PORO & 0.416 & 0.443 \\
\hline 25 & Prod 25 & GBEKE & 0.200 & 0.492 & 105 & Prod105 & PORO & 0.386 & 0.439 \\
\hline 26 & Prod 26 & GBEKE & 0.386 & 0.496 & 106 & Prod106 & PORO & 0.312 & 0.438 \\
\hline 27 & Prod 27 & GBEKE & 0.386 & 0.495 & 107 & Prod107 & PORO & 0.386 & 0.437 \\
\hline 28 & Prod 28 & GBEKE & 0.100 & 0.495 & 108 & Prod108 & PORO & 0.386 & 0.436 \\
\hline 29 & Prod29 & GBEKE & 0.500 & 0.492 & 109 & Prod109 & PORO & 0.386 & 0.435 \\
\hline 30 & Prod30 & GBEKE & 0.500 & 0.492 & 110 & Prod110 & PORO & 0.386 & 0.433 \\
\hline 31 & Prod31 & GBEKE & 0.386 & 0.491 & 111 & Prod111 & PORO & 0.386 & 0.432 \\
\hline 32 & Prod 32 & GBEKE & 0.386 & 0.491 & 112 & Prod112 & PORO & 0.386 & 0.432 \\
\hline 33 & Prod33 & GBEKE & 0.500 & 0.490 & 113 & Prod113 & PORO & 0.386 & 0.431 \\
\hline 34 & Prod34 & GBEKE & 0.386 & 0.489 & 114 & Prod114 & PORO & 0.386 & 0.429 \\
\hline 35 & Prod 35 & GBEKE & 0.416 & 0.489 & 115 & Prod 115 & PORO & 0.386 & 0.427 \\
\hline 36 & Prod36 & GBEKE & 0.386 & 0.489 & 116 & Prod116 & PORO & 0.500 & 0.425 \\
\hline 37 & Prod37 & GBEKE & 0.386 & 0.489 & 117 & Prod117 & PORO & 0.500 & 0.425 \\
\hline 38 & Prod38 & GBEKE & 0.386 & 0.489 & 118 & Prod118 & PORO & 0.308 & 0.425 \\
\hline 39 & Prod39 & GBEKE & 0.386 & 0.489 & 119 & Prod119 & PORO & 0.386 & 0.424 \\
\hline 40 & Prod 40 & GBEKE & 0.298 & 0.489 & 120 & Prod120 & PORO & 0.386 & 0.424 \\
\hline 41 & Prod41 & HAMBOL & 0.386 & 0.489 & 121 & Prod 121 & WORODOUGOU & 0.386 & 0.418 \\
\hline 42 & Prod42 & HAMBOL & 0.500 & 0.489 & 122 & Prod122 & WORODOUGOU & 0.386 & 0.414 \\
\hline 43 & Prod43 & HAMBOL & 0.386 & 0.488 & 123 & Prod123 & WORODOUGOU & 0.386 & 0.408 \\
\hline 44 & Prod44 & HAMBOL & 0.386 & 0.488 & 124 & Prod124 & WORODOUGOU & 0.386 & 0.402 \\
\hline 45 & Prod45 & HAMBOL & 0.386 & 0.488 & 125 & Prod125 & WORODOUGOU & 0.386 & 0.499 \\
\hline 46 & Prod46 & HAMBOL & 0.386 & 0.488 & 126 & Prod126 & WORODOUGOU & 0.416 & 0.499 \\
\hline 47 & Prod47 & HAMBOL & 0.386 & 0.488 & 127 & Prod127 & WORODOUGOU & 0.500 & 0.498 \\
\hline 48 & Prod48 & HAMBOL & 0.386 & 0.487 & 128 & Prod128 & WORODOUGOU & 0.501 & 0.497 \\
\hline 49 & Prod49 & HAMBOL & 0.386 & 0.486 & 129 & Prod129 & WORODOUGOU & 0.500 & 0.494 \\
\hline 50 & Prod50 & HAMBOL & 0.386 & 0.486 & 130 & Prod130 & WORODOUGOU & 0.386 & 0.493 \\
\hline
\end{tabular}




\begin{tabular}{|c|c|c|c|c|c|c|c|c|c|}
\hline$\overline{51}$ & Prod51 & HAMBOL & 0.500 & 0.486 & 131 & Prod131 & WORODOUGOU & 0.386 & 0.489 \\
\hline 52 & Prod52 & HAMBOL & 0.386 & 0.486 & 132 & Prod 132 & WORODOUGOU & 0.386 & 0.487 \\
\hline 53 & Prod53 & HAMBOL & 0.310 & 0.486 & 133 & Prod 133 & WORODOUGOU & 0.386 & 0.487 \\
\hline 54 & Prod54 & HAMBOL & 0.386 & 0.486 & 134 & Prod 134 & WORODOUGOU & 0.386 & 0.478 \\
\hline 55 & Prod55 & HAMBOL & 0.386 & 0.485 & 135 & Prod 135 & WORODOUGOU & 0.500 & 0.475 \\
\hline 56 & Prod56 & HAMBOL & 0.410 & 0.485 & 136 & Prod 136 & WORODOUGOU & 0.386 & 0.462 \\
\hline 57 & Prod57 & HAMBOL & 0.416 & 0.485 & 137 & Prod 137 & WORODOUGOU & 0.386 & 0.459 \\
\hline 58 & Prod58 & HAMBOL & 0.386 & 0.485 & 138 & Prod 138 & WORODOUGOU & 0.500 & 0.459 \\
\hline 59 & Prod59 & HAMBOL & 0.400 & 0.484 & 139 & Prod 139 & WORODOUGOU & 0.386 & 0.456 \\
\hline 60 & Prod60 & HAMBOL & 0.127 & 0.484 & 140 & Prod 140 & WORODOUGOU & 0.386 & 0.456 \\
\hline 61 & Prod61 & HAMBOL & 0.386 & 0.483 & 141 & Prod141 & WORODOUGOU & 0.386 & 0.452 \\
\hline 62 & Prod62 & HAMBOL & 0.386 & 0.482 & 142 & Prod142 & WORODOUGOU & 0.227 & 0.452 \\
\hline 63 & Prod63 & HAMBOL & 0.386 & 0.482 & 143 & Prod 143 & WORODOUGOU & 0.386 & 0.449 \\
\hline 64 & Prod64 & HAMBOL & 0.416 & 0.482 & 144 & Prod144 & WORODOUGOU & 0.386 & 0.447 \\
\hline 65 & Prod65 & HAMBOL & 0.386 & 0.481 & 145 & Prod 145 & WORODOUGOU & 0.386 & 0.445 \\
\hline 66 & Prod66 & HAMBOL & 0.279 & 0.479 & 146 & Prod146 & WORODOUGOU & 0.386 & 0.443 \\
\hline 67 & Prod67 & HAMBOL & 0.500 & 0.479 & 147 & Prod147 & WORODOUGOU & 0.416 & 0.443 \\
\hline 68 & Prod68 & HAMBOL & 0.501 & 0.478 & 148 & Prod 148 & WORODOUGOU & 0.386 & 0.429 \\
\hline 69 & Prod69 & HAMBOL & 0.386 & 0.478 & 149 & Prod 149 & WORODOUGOU & 0.386 & 0.429 \\
\hline 70 & Prod70 & HAMBOL & 0.386 & 0.478 & 150 & Prod 150 & WORODOUGOU & 0.386 & 0.425 \\
\hline 71 & Prod71 & HAMBOL & 0.386 & 0.478 & 151 & Prod151 & WORODOUGOU & 0.386 & 0.417 \\
\hline 72 & Prod72 & HAMBOL & 0.361 & 0.478 & 152 & Prod 152 & WORODOUGOU & 0.072 & 0.415 \\
\hline 73 & Prod73 & HAMBOL & 0.386 & 0.476 & 153 & Prod 153 & WORODOUGOU & 0.386 & 0.404 \\
\hline 74 & Prod74 & HAMBOL & 0.500 & 0.475 & 154 & Prod 154 & WORODOUGOU & 0.386 & 0.457 \\
\hline 75 & Prod75 & HAMBOL & 0.386 & 0.475 & 155 & Prod 155 & WORODOUGOU & 0.500 & 0.456 \\
\hline 76 & Prod76 & HAMBOL & 0.386 & 0.475 & 156 & Prod 156 & WORODOUGOU & 0.386 & 0.455 \\
\hline 77 & Prod77 & HAMBOL & 0.167 & 0.475 & 157 & Prod 157 & WORODOUGOU & 0.386 & 0.454 \\
\hline 78 & Prod78 & HAMBOL & 0.386 & 0.474 & 158 & Prod 158 & WORODOUGOU & 0.386 & 0.354 \\
\hline 79 & Prod79 & HAMBOL & 0.386 & 0.472 & 159 & Prod 159 & WORODOUGOU & 0.400 & 0.354 \\
\hline 80 & Prod80 & HAMBOL & 0.386 & 0.472 & 160 & Prod 160 & WORODOUGOU & 0.386 & 0.404 \\
\hline
\end{tabular}

The distribution of technical efficiencies from our estimations shows that they are centred around 0.4 (Figure 1) and $0.4-0.5$ (Figure 2) as variable return to scale and constant return to scale respectively.

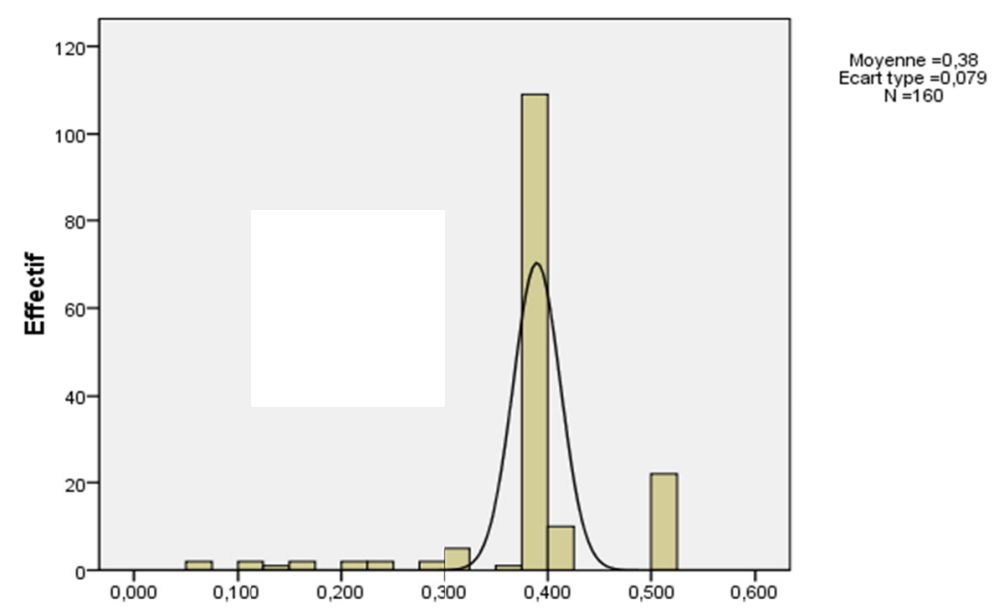

Figure 1. Kernel density of technical efficiency in constant return to scale 


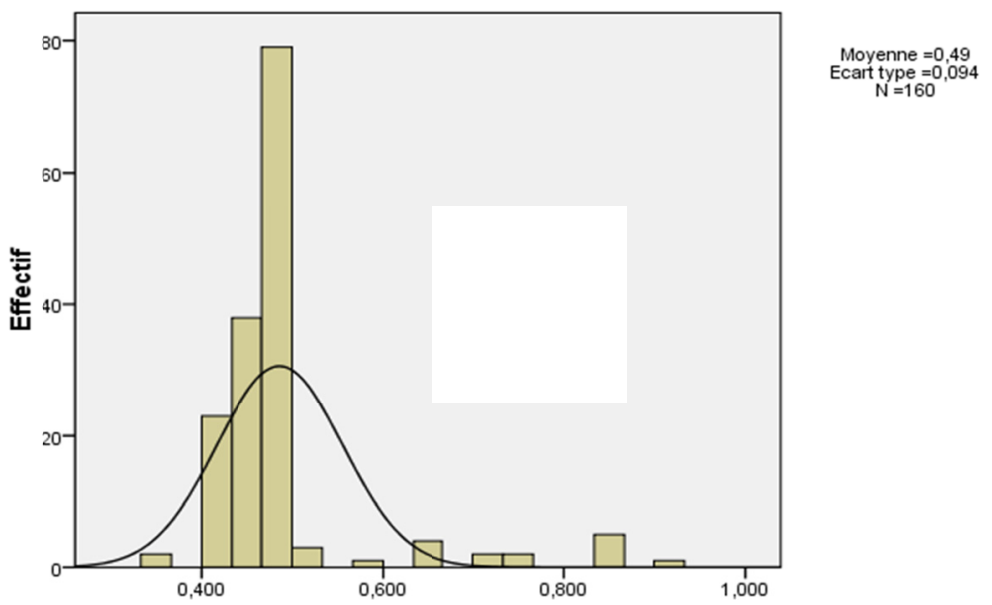

Figure 2. Kernel density of technical efficiency in variable return to scale

To measure the technical efficiency of farms, in practice, two linear programming models are used: The first one measures the overall technical efficiency by estimating a production frontier in constant return to scale. This is known as Overall Technical Efficiency (OTE). The second one measures Pure Technical Efficiency (PTE), considering the variable return to scale assumption. The transition from one assumption to another requires a scale of change called Scale Technical Efficiency (STE), which is obtained in a residual way using the ratio of the overall technical efficiency score to that of pure technical efficiency.

Ultimately, overall technical efficiency (Constant Return to Scale assumption) combines two components, i.e., pure efficiency (Variable Return to Scale) and Scale Technical Efficiency, as follows:

$$
\mathrm{OTE}=\mathrm{PTE} \times \mathrm{STE}
$$

A company is said to perform well and is considered as "best practice" for others when its efficiency score is equal to one. Table 8 presents the results of the DEA model by region assuming Variable Return to Scale (VRS), Constant Return to Scale (CRS) and Scale Technical Efficiency (STE). This table contains the average efficiency scores assuming constant returns to scale (OTE), which is also overall efficiency. The total efficiency consits of pure efficiency (efficiency assuming variable return to scale (PTE) and Scale Technical Efficiency (STE).

Table 8. Producer efficiency scores by region in percentage terms

\begin{tabular}{llll}
\hline Regions & Technical efficiency in CRS (OTE) & Technical efficiency in VRS (PTE) & Scale efficiency (STE) \\
\hline GBEKE & $58.9 \%$ & $64.6 \%$ & $91.7 \%$ \\
HAMBOL & $34.4 \%$ & $47.6 \%$ & $73.5 \%$ \\
PORO & $53.9 \%$ & $65.0 \%$ & $83.8 \%$ \\
WORODOUGOU & $58.5 \%$ & $72.1 \%$ & $82.5 \%$ \\
\hline Total & $38.3 \%$ & $49.2 \%$ & $80.2 \%$ \\
\hline
\end{tabular}

In all four regions surveyed, the average technical efficiency is $49.2 \%$ VRS and $38.3 \%$ CRS, with a Scale Technical Efficiency (STE) of approx. 80.2\%. Based on our results, farms in the four regions are technically inefficient. The comparative analysis shows that two regions are always well ranked regardless of the yield assumptions used. These are Worodougou-ranking $2^{\text {nd }}$ in Constant Return to Scale (CRS) and 1st in Variable Return to Scale (72.1\%), and Gbêkê — ranking 1st in Constant Return to Scale (58.9\%) and 3rd in Variable Return to Scale (VRS). Whatever the yield assumption, the Hambol region remains the last of the four regions in terms of efficiency. The observed inefficiency could be explained by the mismanagement of inputs by producers. This input wastage also leads to additional production costs. However, the Worodougou region's technical efficiency advantage over the other regions may be due to good rainfall in the area because of the forest in the region.

\subsection{Measurement of Producer Technical Efficiency by Class}

Based on good practice criteria according to coaching organizations, i.e., cleaning, fireguard, pruning, thinning, and on-farm use of insecticide and herbicide, farms can be categorised into three (3) classes: the best (40 farms), 
the average ones ( 40 farms) and the small ones ( 35 farms). Technical efficiency for these farms was measured according to this categorization. The results obtained are compiled in Table 9. Our results show that in Variable Return to Scale (VRS), low-class producers have a higher efficiency index than high-class producers. In Constant Return to Scale (CRS), the weakest rank second behind the class of farms that are said to be the best or strong.

Table 9. Producer efficiency scores by class in percentage terms

\begin{tabular}{llll}
\hline Regions & Technical efficiency in CRS (OTE) & Technical efficiency in VRS (PTE) & Scale technical efficiency (STE) \\
\hline WEAK (35 farms) & $52.6 \%$ & $74.2 \%$ & $71.9 \%$ \\
AVERAGE (40 farms) & $39.1 \%$ & $50.3 \%$ & $78.7 \%$ \\
STRONG (40 farms) & $61.2 \%$ & $70.2 \%$ & $85.2 \%$ \\
\hline Total & $38.3 \%$ & $49.2 \%$ & $80.2 \%$ \\
\hline
\end{tabular}

We believe that the better efficiency in the weak farms class is due to the rationality of producers in this class, who waste less inputs. Producer coaching organizations favor productivity over rational input management and farm surface control. These results show that the higher the size of the farm, expressed in hectare of planted area, the less efficient the management. Especially as farms operate in a hostile environment (climate, lack of proven technological progress, lack of funding, difficult access to roads, poor supervision, etc.). These results also reflect perhaps a limitation of the Data Envelopment Analysis (DEA) compared to financial measures that incorporate the market price of inputs and outputs. The Data Envelopment Analysis (DEA) or technical efficiency measurement reflects the managerial efficiency of the production system. These results also reflect the competing objectives between the coaching organization pursuing farm capitalization, and a destitute farm manager or producer who wants to maximize his profit. Productivity is a simple-looking indicator that measures the relationship between production and the factors required to achieve it. This is the primary indicator of the farmer's or farm manager's dashboard. For a destitute producer, local agricultural productivity is one of the drivers of economic growth; and the analysis of agricultural performance helps identify priorities to be defined in terms of agricultural strategies, accompanying measures, and support required. This leads them to be more rational in the use of production factors. We supplement our analysis with regression studies to incorporate exogenous factors - at least some of them-which may explain the observed efficiencies.

\subsection{Analysis of Determinants of Producer Technical Efficiency}

The TOBIT model yielded the results reported in Table 10. They show significant correlation at different levels of significance, and signs between efficiency indices and some factors. Our results show that the determinants of producer technical efficiency are "farm age", "dedicated agricultural advisory service" and "Pruning". The other factors are not significant but affect producers' technical efficiency positively or negatively.

Table 10. TOBIT results

\begin{tabular}{lllll}
\hline Variables & Coefficient & Std error & $\mathbf{z}$ & Critical p. \\
\hline Consistency & $0.453123^{* * *}$ & 0.170338 & 2.6601 & 0.00781 \\
Educational level & -0.0456175 & 0.0485794 & -0.9390 & 0.34771 \\
Experience & 0.00181162 & 0.00415628 & 0.4359 & 0.66293 \\
Agricultural advisory service & $\mathbf{0 . 1 3 5 0 8}{ }^{* * *}$ & $\mathbf{0 . 0 5 1 9 8 4 1}$ & $\mathbf{2 . 5 9 8 5}$ & $\mathbf{0 . 0 0 9 3 6}$ \\
Sex & 0.0630268 & 0.0778211 & 0.8099 & 0.41800 \\
Farmer age & $\mathbf{0 . 0 0 5 2 7 5 7 ^ { * }}$ & $\mathbf{0 . 0 0 3 1 3 5 1 3}$ & $\mathbf{1 . 6 8 2 8}$ & $\mathbf{0 . 0 9 2 4 2}$ \\
Clearing & 0.0101493 & 0.120204 & 0.0844 & 0.93271 \\
Fireguard & -0.020125 & 0.0775157 & -0.2596 & 0.79515 \\
Thinning & 0.0407037 & 0.0560915 & 0.7257 & 0.46804 \\
Pruning & $\mathbf{- 0 . 1 0 8 5 5 3 *}$ & $\mathbf{0 . 0 5 2 3 7 0 8}$ & $\mathbf{- 2 . 0 7 2 8}$ & $\mathbf{0 . 0 3 8 1 9}$ \\
Area & -0.00436376 & 0.00486784 & -0.8964 & 0.37001 \\
\hline Ne. Level of significance $*=10 \% * * *=5 \% \cdot * * *=1 \%$ & & &
\end{tabular}


The "Agricultural Advisory Service" variable is significant at 1\%, and positively impacts efficiencies. This is in line with our expectations because producers who are provided with agricultural advisory service receive more information and more pragmatic guidelines to improve their production. This positive correlation is explained by the fact that good practices improve agronomic conditions for good production. But unfortunately, these good practices generate additional costs, which the additional production in value, can not support. This is why producers who follow good practices are not technically efficient, as our results above show. The "Farm Age" variable is significant at $10 \%$, and has a positive impact on efficiencies. This means that the oldest farms (more than 25 years old) produce less than the youngest ones, according to a study by the Initiative Cajou Africain (ICA-African Cashew Initiative) and GIZ, which shows that production reaches its maximum between 15 and 20 years, and decreases from the age of 20. Eddy (2017) obtained this result. Kane (2010) and Koné (2015) also found that farm age improved efficiency. The "Pruning" variable is significant at $5 \%$, and adversely impacts efficiencies. Such result is counter-intuitive because this practice eliminates poorly growing, diseased or dead branches to improve productivity. However, the result can be explained by poor implementation of related advice. Indeed, if producers do not sort branches properly, it is normal to achieve poor performance. In addition, the negative impact is short term because a few months later, the cut branches will resume producing. In view of our results, we recommend that cashew producers take literacy classes regardless of their age in order to better understand training and benefit from new technologies in the field; they should join peasant professional organizations to receive training, avoid input wastage as this leads to additional production costs and makes the farms less efficient. They should properly implement maintenance practices, especially pruning, to avoid any counter-effect. As for coaching organizations, we recommend that they use this approach for measuring the technical efficiency and/or financial productivity of farms, and Tobit-type regression models to guide the accompanying strategies. We suggest they capitalize on factors that are exogenous to farms and can improve their efficiency.

\subsection{Analysis of Poverty}

Poverty is defined as a situation where a person does not have sufficient income to meet their basic needs (food, housing, clothing, health care, and schooling). Poverty line is the indicator of poverty measurement, while the Gini index (or coefficient) is a synthetic indicator of wage inequalities (income, living standards, etc.). It varies between 0 and 1 . It is 0 in a situation of perfect equality where all wages, incomes, standards of life are equal. It is 1 in the most unequal situation possible one where all wages (income, living standards, etc.) except one are zero. Between 0 and 1 , the inequality is stronger when the Gini index is high. To understand poverty in the study area, we estimated farming income. The enrichment of farms, and the income per person per year and per day were estimated. This data tabulated below will be compared to the poverty and extreme poverty indicators shown in the table 11 .

Table 11. Evolution of poverty lines in current francs during the surveys

\begin{tabular}{llllllll}
\hline Year & $\mathbf{1 9 8 5}$ & $\mathbf{1 9 9 3}$ & $\mathbf{1 9 9 5}$ & $\mathbf{1 9 9 8}$ & $\mathbf{2 0 0 2}$ & $\mathbf{2 0 0 8}$ & $\mathbf{2 0 1 5}$ \\
\hline Poverty line (in F/year) & 75000 & 101340 & 144800 & 162800 & 183450 & 241145 & 269075 \\
Extreme poverty line (in F/year) & & 63375 & 86760 & 95700 & 94280 & 101826 & 122385 \\
\hline
\end{tabular}

Source: Ministère du Plan et du Développement, INS-ENV (2015) and previous years.

National poverty line in the global economy is estimated at CFA F 269,075/year/person, or CFA F 737/day/person. Extreme poverty line is estimated at CFA F 122,385/year/person, or CFA F 340/day/person (Ducroquet, H., 2017). This indicator in the cashew sector, based on the income procured, is estimated at 380.650 billion CFA F in 2018; the income/person/year is estimated at CFAF 158.604 or CFA F 441/day/person. This shows that cashew farmers nationwide have an income below poverty line and can be considered as poor.

The income in CFA F/person/year for producers in the study area is estimated at 37,987 in the Gbêkê region; 21,816 in the Hambol region; 36,630 in the Poro region; and 37,476 in the Worodougou region (Table 12). These incomes are all below the extreme poverty line estimated at 122,385 CFAF/person/year. With such a level of income (less than 1 dollar/day/person), the producer only survives, and cannot capitalise on his farm. This low financial profitability of cashew farms is due to the low producer price, which is indexed to the international market price, to the small size and the low yield of farms. Knowing that he does not have enough financial resources, the producer does not seek to be a good applicator of good practices that require resources. He rather wants to be rational, and therefore a good manager. This is why smallholders, and those who are not good 
practitioners, are the most financially efficient in our study. In this sense, it is easy to understand why producers do not follow the coaching organizations' guidelines for good farming practices.

Table 12. Producer farming income by region

\begin{tabular}{lllll}
\hline & \multicolumn{3}{c}{ Regions } \\
\cline { 2 - 5 } & GBEKE & HAMBOL & PORO & WORODOUGOU \\
\hline Average farm area in Ha & 3 & 3 & 3 & 3 \\
GROSS PRODUCT (PBA) IN CFAF & $\mathbf{5 9 2} \mathbf{2 0 0}$ & $\mathbf{3 7 4} \mathbf{8 5 0}$ & $\mathbf{5 5 8} \mathbf{6 0 0}$ & $\mathbf{4 5 5} \mathbf{7 0 0}$ \\
Yield in Kg & 564 & 357 & 532 & 434 \\
Average selling price in Kg & 350 & 350 & 350 & 350 \\
VARIABLE COSTS IN CFAF & 276725 & 185235 & 252000 & 144120 \\
Insecticide in CFAF & 2450 & 7560 & 19650 & 9330 \\
Herbicide in CFAF & 35955 & 26850 & 32160 & 37500 \\
Fertiliser in CFAF & 1500 & 825 & 2250 & 3450 \\
Other expenses (fuel, transport, bag, string) in CFAF & 30075 & 15660 & 28290 & 10245 \\
Small farm equipment in CFAF & 25080 & 16035 & 38085 & 16515 \\
Casual labour in CFAF & 211740 & 118305 & 131565 & 67080 \\
FIXED COSTS IN CFAF & 11580 & 15090 & 13560 & 11775 \\
Depreciation allowance & 11580 & 15090 & 13560 & 11775 \\
FARMING INCOME IN CFAF/YEAR/FARM & 303895 & 174525 & 293040 & 299805 \\
Average size of households & 8 & 8 & 8 & 8 \\
Farming income/year/person in CFAF & $\mathbf{3 7 9 8 7}$ & $\mathbf{2 1 ~ 8 1 6}$ & $\mathbf{3 6 ~ 6 3 0}$ & $\mathbf{3 7 4 7 6}$ \\
Farming income/day/person in CFAF & $\mathbf{1 0 5}$ & $\mathbf{6 1}$ & $\mathbf{1 0 2}$ & $\mathbf{1 0 4}$ \\
\hline Source: Survey data, 2018. & & &
\end{tabular}

Source: Survey data, 2018.

The financial inefficiency of good practitioners is due to the more than proportional rise in input prices relative to the physical productivity of farms. These realities are very often poorly taken into account by coaching organizations in developing agricultural technical itineraries. At the macro-economic level, poverty rate dropped from $48.9 \%$ in 2008 to $46.3 \%$ in 2015 because of the economic recovery combined with the efforts made by the Government to improve living conditions. The poverty rate dropped from $62.5 \%$ to $56.8 \%$ in rural areas, while in urban areas, it dropped from $29.5 \%$ to $35.9 \%$ because of rural exodus. This shows that poverty is essentially rural. Also, the spatial distribution of poverty reveals that it is higher in northern regions (high cashew producing area) and lower in southern regions (cocoa producing area). In our study area, poverty ranges from 51.5 to $59.9 \%$ and is above the national average (46.3\%) according to FMI (2016). The Gini index shows that inequalities are gradually being reduced in Côte d'Ivoire. It was 0.405 in 2015 vs 0.420 in 2008 and 0.500 in 2002 (UNDP, 2017). In all regions of the project area, this indicator is estimated at 0.398 and is close to the national benchmark $(0.380)$ according to FMI (2016).

Cashew farming also raises an acute problem of food security in terms of non-availability of land for subsistence agriculture and of deteriorating cashew/food terms of trade, as confirmed by Kouakou et al. (2017). According to this author, in 1999, 1 kilogram of cashew nut was needed to buy two kilograms of rice. However, in $2013,7 \mathrm{~kg}$ of cashew were traded for 1 kilogram of low quality rice sold at 350 CFAF. Beyond monetary gains, cashew production involves other underlying interests. The determinants of cashew farming are also psychological. According to Kouakou et al. (2017), some people own large areas of orchards and take pride in them not for monetary profitability, but rather to appear as big farmers. Because of this activity, they have easy access to credit in their community when in need. Also, the cashew tree, a perennial crop, allows people to own land permanently. It is an opportunity to acquire land ownership rights because no one can snatch a plot on which trees have been planted. Cashew thereby becomes legal proof of land ownership. So, very often, improving yield to increase farming income is not a priority, compared to land race. It can therefore be argued that cashew farming seems to be a virtuous circle of poverty. And when a cashew producer does not get enough income to live on, he is forced to engage in other activities such as food crops, vegetable crops, trade etc. All the activities conducted by a producer to get income in order to live determine his production system. To innovate in our environment, we should deepen our knowledge of our environment, our land and labour constraints, and our 
priorities, etc. or our production system in order to minimize the risk of failure. This justifies, as Stessen (2002) and Boserup (1965) argued, that it is necessary to always study production systems in order to avoid technical innovation adoption failures.

\section{Conclusion}

The study reveals that with regard to efficiency, whether in terms of constant or variable return to scale, the farms in the study area as a whole are not technically efficient $(49.2 \%$ in Variable Return to Scale and $38.3 \%$ in Constant Return to Scale). However, comparatively, the Worodougou region is doing better at $72.1 \%$ in VRS, and the region with the lowest efficiency is Hambol with $47.6 \%$ in VRS. Regarding the three classes' efficiency in terms of good practice, it should be remembered that the farm group with low application of good agricultural practices has the best rate of technical efficiency (74.2\% in Variable Return to Scale).

The "Agricultural advisory service" variable is significant at $1 \%$ and positively impacts efficiencies. This positive correlation is explained by the fact that, good practices improve agronomic conditions for good production. But unfortunately, these good practices generate additional costs, which the additional production in value, can not support. This is why producers who follow good practices are not technically efficient, as our results above show. The "Farm Age" variable is significant at $10 \%$ and has a positive impact on efficiencies. This means that the oldest farms (more than 25 years old) produce less than the youngest ones, according to a study by the Initiative Cajou Africain (ICA-African Cashew Initiative) and GIZ, which shows that production reaches its maximum between 15 and 20 years, and decreases from the age of 20. Eddy (2017) got such a result. Kane (2010) and Koné (2015) also found that farm age improved efficiency. The "Pruning" variable is significant at $5 \%$ and adversely impacts efficiencies.

The poverty analysis has shown that, at the national level, the cashew sector provides agricultural producers with an income of CFA F 158,604/person/year, or CFA F 441/day/person. This income is below the poverty line estimated at CFAF 269,075/year/person, or CFA F 737/day/person. The income in CFA F/person/year for producers in the study area is estimated at 37,987 in the Gbêkê region; 21,816 in the Hambol region; 36,630 in the Poro region; and 37,476 in the Worodougou region. All these incomes are below the extreme poverty line estimated at CFA F 122,385/person/year. With such a level of income (less than a dollar/day/person), the producer only survives, and cannot capitalise on his farm. Knowing that he does not have enough financial resources, the producer does not seek to be a good applicator of good practices that require resources. He rather wants to be rational, and therefore a good manager. This is why smallholders and those who are not good practitioners are the most financially efficient in our study. In this sense, it is easy to understand the reasons why producers do not follow coaching organizations' guidelines for good farming practices. Cashew farming also raises an acute issue of food security in terms of non-availability of land for subsistence agriculture and of deteriorating cashew/food terms of trade. It is used not necessarily to get income, but to acquire land ownership rights, to be held in esteem in society and to get financial credit. It can therefore be argued that cashew farming seems to be a virtuous circle of poverty. This is why we believe, like Etessen (2002) and Boserup (1965), that for a technological innovation to be successfully adopted, it is essential to carry out an in-depth analysis of the producer's production system in terms of its efficiency and of the determinants for its proper functioning.

In view of the foregoing, it can be argued that cashew farming is not financially profitable for the majority of producers, but economically profitable because it provides income for many people and businesses. Cashew farming has helped improve poverty indicators through macroeconomic policy. However, this impetus from the agricultural sector economy remains insufficient to boost the modernization of the agricultural sector. The country still has all assets (research institutes, schools of agronomy, skills, etc.) to reverse this situation.

The study recommends that producers capitalize on exogenous variables which can improve farm efficiency, such as farm age, agricultural advisory services, and good pruning practice. It recommends that coaching organizations use technical efficiency measurement, and efficiency determinants identification to better guide their support. Cashew has been introduced in these four regions to revive and support their economies. The low profitability of cashew farms illustrated in this study requires that the Government redouble its efforts to address the identified failures and to implement the recommended solutions, in order to avoid a pauperization of producers, resulting in rural exodus, thereby undermining the harmonious development of the Ivorian economy.

\section{References}

Adaman, S., \& N'Dri, K. A. (2016). Impacts Socio-Economiques de la Culture de L'anacarde Dans la Sous-Préfecture D’Odienné (Côte d'Ivoire). European Scientific Journal, 12(32), 369-383. https://doi.org/ 10.19044/esj.2016.v12n32p369 
Ambapour, S. (2001). Estimation des frontières de production et mesures de l'efficacité technique. Bureau d'application des méthodes statistiques et informatiques (p. 26). Retrieved from http://www.cnsee.org/ Publication/PDF/BAMSI02.pdf

Balogoun, I., et al. (2014). Caractérisation des systèmes de production a base d'anacardier dans les principales zones de culture au Benin. Agronomie Africaine Côte d'Ivoire, 26(1), 9 -22.

Banker, R.-D., Charnes, A., \& Cooper, W.-W. (1984). Some models for estimating technical and scale inefficiencies in data envelopment analysis. Management Science, 30, 1078-1092. https://doi.org/10.1287/ mnsc.30.9.1078

Benido, C. D. B. (2016). Analyse des déterminants de l'adoption des bonnes pratiques de production de l'anacarde au Burkina Faso (p. 77). Mémoire de Maîtrise, Université Laval, Québec, Canada.

Berger Allen, N., \& Humphrey David, B. (1997). Efficiency of financial institutions: International survey and directions for future research. European Journal of Operational Research, 98(2), 175-212. https://doi.org/ 10.1016/S0377-2217(96)00342-6

Boussemart, J.-P., \& Dervaux, B. (1994). Diagnostic de l'efficacité productive par la méthode DEA, Application à des élevages porcins. Cahiers d'Économie et Sociologie Rurales, 31, 44-58. Retrieved from http://ageconsearch.umn.edu/bitstream/234135/2/CESR-31-43-58.pdf

Charnes, A., Cooper, W.-W., \& Rhodes, E. (1978). Measuring the efficiency of decision making units. European Journal of Operational Research, 2, 429-444. https://doi.org/10.1016/0377-2217(78)90138-8

Coelli, T., Rao, D. S. P., \& Battese, G. E. (1998). An introduction to efficiency and productivity analysis (2nd ed.). Kluwer Academic Publisher, Boston. https://doi.org/10.1007/978-1-4615-5493-6

Conseil du Coton et de l'Anacarde. (2017). Rapport Annuel d'Activités (pp. 6-18).

Deloitte. (2017). Etude relative à la compétitivité du secteur de la transformation de l'anacarde en Côte d'Ivoire (pp. 13-53).

Djimasra, N. (2010). Efficacité technique, productive et compétitivité des principaux pays producteurs de coton (p. 429, Thèse pour l'obtention du grade de Docteur de l'Université d'Orléans).

Eddy, B. (2017). Analyse de l'efficacité technique des exploitations d'anacardiers en Côte d'Ivoire. Revue internationale de gestion et d'économie série b-économie (Numéro 3, Volume 1, pp. 160-186). Retrieved from http://www.rige2016.net

FIRCA. (2018). La filière Anacarde-Acte 20. Magazine d'information (p. 56)

FMI. (2016), Plan National de Développement (PND 2016-2020), Diagnostique de la Côte d'Tvoire sur la trajectoire de l'émergence; Tome 1, Côte d'Ivoire (pp. 1-6)

Huguenin, J.-M. (2013). Data Envelopment Analysis (DEA), Un guide pédagogique à l'intention des décideurs dans le secteur public. IDHEAP-Cahier 278/2013 Chaire Finances publiques (p. 90). Retrieved from https://serval.unil.ch/resource/serval:BIB_2EF374911F7A.P001/REF

Kane, G. Q. (2010). Analyse des performances productives des exploitations familiales agricoles de la localité de Zoetelé. Mémoire de fin d'études en vue de l'obtention du DEA/Master en Sciences Economiques (pp. 12-27). Rtrieved from https://www.memoireonline.com/02/11/4237/m_Analyse-des-performances-producti ves-des-exploitations-familiales-agricoles-de-la-localite-de-Zoete $0 . \mathrm{html}$

Kone Aïcha. (2015). Analyse de la pauvreté et de l'efficacité technique des producteurs de cacao de la société coopérative agricole de la Méné (camene.coop-ca). Mémoire de fin d'études pour l'obtention du diplôme d'ingénieur agronome option: Agroéconomie (pp. 1-56).

Kouakou, K. A., et al. (2017). Impact de la culture de l'anacarde sur la sécurité alimentaire dans le département de Bondoukou. Revue de Géographie Tropicale et d'Environnement, 2, 7-16.

Leibenstein, H. (1978). General X-Efficiency Theory and Economic Development. Oxford University Press.

Ministère de l'Agriculture et du Développement Rural. (2013). Document d'opérationnalité de la réforme de la filière anacarde (p. 8-75).

Ministère du Plan et Développement. (2015). Enquête sur le Niveau de Vie des Menages en CI (ENV 2015) (p. 91). Institut National de la Statistique. 
Ministère du Plan et Développement. (2015). Etudes Monographiques des Districts de Côte d'Tvoire (pp. 25-64). District du Woroba, District des Savanes, District d la Vallée du Badaman.

Ndiaye, M. (2018). Analyse de l'efficacité technique des exploitations agricoles familiales à Maurice. European Scientific Journal, 14(9), 143. https://doi.org/10.19044/esj.2018.v14n9p143

Nuama, E. (2006). Mesure de l'efficacité technique des agricultrices de cultures vivrières en Côte d'Ivoire. Économie Rurale (pp. 39-53, 296, Novembre-Décembre 2006). https://doi.org/10.4000/economierurale.1892

Nuama, E. (2010). L'efficacité technique des riziculteurs ivoiriens: La vulgarisation en question. Économie Rurale (pp. 36-47, 316, Mars-Avril 2010). https://doi.org/10.4000/economierurale.2598

Ouattara, G. M. (2017). Les déterminants de l'adoption de certaines bonnes pratiques culturales avant récolte de la noix de cajou en Côte d'Ivoire. IOSR Journal of Economics and Finance, 8(3).

Paraïso, A. A., Sossou, A. C. G., Yegbemey, R. N., \& Biaou, G. (2010). Analyse de la rentabilité de la production du fonio (digitaria exilis s.) dans la commune de boukombé au Benin. J. Rech. Sci. Univ., 13(1), 27-37.

PSAC. (2017). Elaboration de la situation de référence du PSAC filière anacarde.

Soegbe Sewade, G. (2010). Contribution a la mesure de l'efficacite technique des exploitations agricoles au Benin: Cas des perimetres rizicoles du projet d'hydraulique pastorale \& agricole (PHPA). Mémoire propedeutique pour l'obtention du master de recherche en sciences de gestion (p. 72). ISOR, Bénin.

Stessens, J. (2002). Analyse technique et économique des systèmes de production agricole au nord de la Côte d'Ivoire (p. 286, Thèse de Doctorat, K.U. Leuven, Belgique).

Tobin, J. (1958). Liquidity Preference as Behavior Towards Risk. The Review of Economic Studies, 25(2), 65-86. https://doi.org/10.2307/2296205

Wampach, J.-P. (1983). Productivité, efficacité économique et équité dans le secteur agricole québécois. In Revue L'Actualité économique, 59(4), 641-783. https://doi.org/10.7202/601072ar

\section{Copyrights}

Copyright for this article is retained by the author(s), with first publication rights granted to the journal.

This is an open-access article distributed under the terms and conditions of the Creative Commons Attribution license (http://creativecommons.org/licenses/by/4.0/). 